\title{
Returns to Investors in Stocks in New Industries
}

\author{
Cora Barnhart \\ Palm Beach Atlantic University \\ Gerald P. Dwyer, Jr. \\ Federal Reserve Bank of Atlanta \\ University of Carlos III, Madrid
}

October 2007

\begin{abstract}
We examine the returns to investors in publicly traded stock in new industries. We examine data from the United States on sellers of own-brand personal computers, airlines and airplane manufacturers, automobile manufacturers, railroads and telegraphs. A relatively small number of companies generate outstanding returns and many firms fail in some new industries. We find that firms in new industries typically have high volatility of individual stocks' returns and high expected returns relative to indexes for the same period. Portfolios of firms in new industries generally have lower Sharpe ratios than the overall market.
\end{abstract}

Acknowledgement 1 We thank Paula Tkac for numerous helpful comments. We also thank Mark Fisher and other members of a brown bag lunch at the Federal Reserve Bank of Atlanta for comments that substantially improved the 
paper. Ann Gillette, Scott Hein, Delroy Hunter and Cesare Robotti provided helpful comments on earlier drafts. We have received helpful comments from participants at seminars at the Bank of Finland, the City University Business School in London, EDHEC, the University of Carlos III and the University of Georgia. Pam Frisbee, Budina Naydenova and Shalini Patel provided excellent research assistance and Linda Mundy put everything together. The views expressed here are the authors' and not necessarily those of the Federal Reserve Bank of Atlanta or the Federal Reserve System. Any errors are the authors' responsibility.

\section{INTRODUCTION}

One thousand dollars invested in America Online's IPO in March 1992 became $\$ 295,545$ by the end of 2000 when AOL was purchased by Time-Warner. This is an extraordinary payoff for shareholders - over five percent per month. While high, new industries have high risk and stocks may be likely to have high expected returns. On the other hand, the extraordinary behavior of dot-com stocks make this conclusion less than obvious.

The stratospheric prices of dot-com stocks and returns to some shareholders suggest that expected returns in a new industry may well be dominated by aspects of returns not typical in more mature industries. One possibility is euphoria or craziness, an explanation given more plausibility by the boom and bust in dot-com stock prices. Another explanation is that such stocks are similar to options and lottery tickets. This possibility has occurred to many observers, among them Alan Greenspan who observed that "When you are dealing with stock the possibilities of which are either it's going to be valued at zero or some huge number - you get a premium in that stock price which is exactly the same sort of price evaluation process that goes on in the lottery." [Blumberg Capital 1999]. Perhaps stocks in new industries have a 
distribution of returns that includes the possibility of large gains and small losses? If so, then investors may buy stocks for the same reasons that people are willing to pay for lottery tickets. This explanation could be consistent with high valuations and even negative expected returns because investors are willing to pay on average to have a small probability of a large gain.

Indeed, the limited history of dot-coms suggests realization of substantial negative returns. The average geometric return to shareholders across dot-coms is -4.3 percent per month. Even so, the history of dot-coms probably is too short to deliver very reliable evidence on the expected return in new industries. This average return to stockholders is based on the same firms as in Hand [2001], but there are only five firms in the CRSP data for these firms as recently as 1995.

In this paper, we estimate expected returns in new industries by examining new industries with longer experiences than dot-coms. Many analogies have been drawn between dot-coms and earlier industries as far back as railroads and telegraphs, e.g. in Business Week [Mandel 1999, Hof and Hamm 2002, Nairn 2002] and the Economist [Economist 2000]. ${ }^{1}$ Among these analogies is the importance of network effects. Network effects are important for dot-coms and they are important for some of the industries examined in this paper. Some prior industries are network industries if a network industry is defined as one in which a standard for the product or the availability of complementary inputs have high marginal value for the industry. One of the industries included in the analysis in this paper is the automobile industry, which standardized on gasoline engines instead of electricity or steam. In addition, we examine the telegraph industry, for which interconnection is as crucial as for the Internet. While it is less obvious, interconnection also is an important issue for railroads as well. When differences in track width - gauge - are large enough, connections across

\footnotetext{
${ }^{1}$ On a longer time scale, Jensen [1993] draws lessons for what he calls the Third Industrial Revolution since 1973 from earlier ones.
} 
lines can require unloading and reloading railroad cars. Gauge was not standardized in the U.S. until the 1880s and even today, gauge in Spain and Portugal is different than in the rest of Europe.

In this paper, we examine the returns in major, new industries in the United States and summarize the distribution of returns over the period of the development of the industry. Our paper is related to recent papers by Cochrane [2005], Fama and French [2001] and Gompers and Lerner [2003.] Cochrane examines the distribution of returns to firms financed by venture capital and finds that their expected proportional returns are quite high, on the order of 50 percent per year. Fama and French [2001] examine the returns on newly listed firms in the CRSP dataset from 1926 to 2000 and find that these firms' returns are similar to their benchmark returns. Gompers and Lerner [2003] find that returns on initial public offerings (IPOs) before NASDAQ are similar to their benchmark returns. Our paper is both narrower and broader than these papers. Our paper is narrower because we do not examine the returns to investors in all new firms; we examine the returns only for firms in new industries. Our paper is broader because we would have relatively few industries if we limited our analysis to the CRSP dataset. We extend the data back before 1926 in order to obtain evidence on more than just a couple of new, major industries. Our paper also is related to Pástor and Veronesi's [2005] analysis of technological revolutions and stock prices. We do not develop or illustrate a particular theory, but we examine the distribution of returns in several earlier industries using statistical analysis in a way that lets us draw inferences about those returns.

In the first section of the paper, we examine the distribution of returns in the personal computer industry. The IBM PC was introduced in 1981 and detailed information on this industry is readily available.

Next, we examine the distributions of returns in major new industries in earlier time periods. We analyze the airline and aircraft industries, automobile production, 
railroads and the telegraph industry. These industries are associated with major changes in transportation and communications in the United States and had widespread effects on the rest of the economy. ${ }^{2}$

We examine returns over the first 15 or 20 years or so after an industry begins to develop. This is long enough to be interesting but not so long as to require the implicit assumption that investors at the beginning of an industry foresee developments a half century or more later. Our analyses end at the start of major, largely unforeseen disruptions such as wars or the Great Depression, disruptions that are not industryspecific.

Our evidence shows that public investors can expect to receive returns on stocks in new industries that are positive and broadly in line with market returns. Our results are comparable in that respect to results found by Cochrane [2005], Fama and French [2001] and Gompers and Lerner [2001]. The data show some evidence of small probabilities of large gains and high probabilities of small losses, but they generally are not dramatically inconsistent with a log-normal distribution's implied skewness of payoffs. Sharpe ratios indicate that portfolios of stocks in firms in new industries are not an obvious bad deal, but such portfolios are dominated by diversified portfolios spanning the market.

\footnotetext{
${ }^{2}$ It is not hard to think of other industries that could be studied. For example, the telephone industry had large effects on communication, but it would not be very informative because its early history is one of monopoly due to patents, followed by a short window of competition and then overwhelming regulation [Weiman and Levin 1994]. The electric power industry is another obvious candidate, but its evolution also was heavily affected by patents and regulation. Other industries such as the frozen pizza industry might well be interesting, but our results are more to the point if the large majority of firms are startups that primarily do business in that industry.
} 


\section{PERSONAL COMPUTERS}

Personal computers have been around for more than a quarter of a century, so the personal computer industry is an obvious one in which to examine the distribution of stock returns. High returns are easy to see at a glance. Two well known firms have very high returns: Dell and Apple. One thousand dollars invested in Dell Computer Corp. in June 1988 when it started trading on public exchanges became $\$ 256,922$ by the end of December 2006. This is an annual average proportional return on the order of 35 percent per year for 18 and a half years. One thousand dollars invested in Apple in December 1983 became $\$ 30,524$ by December 2006. While less spectacular than the payoff to investors in Dell, this investment has an annual average return on the order of 16 percent per year for over twenty years. While these firms are unlikely to be typical, what are a typical investor's returns from a new firm in the PC industry?

\section{The Distribution of Returns}

We use data from CRSP to estimate the distribution of returns to investors in publicly traded firms that make own-brand personal computers. ${ }^{3}$ We compute rates of return on all such firms. Table 1 provides a summary of the returns on those stocks. These data are for firms in the personal computer industry, even though some firms such as IBM do not receive their primary revenue from making PCs. The returns are average proportional returns with annual compounding. The returns for the whole period are from December 1983 through December 2006. If the whole period is not available, we compute the return for the period for which market prices are available. When a firm disappears from the CRSP files, we end the computations for the firm

\footnotetext{
${ }^{3}$ We leave out UNIX personal computers because of their significantly higher prices for computers and software.

More details on the collection of data are available in the Data Appendix available on request.
} 
even if the firm merged into another firm, as did Zeos into Micron. Because we are attempting to measure returns, not duration of existence, this procedure seems better than making choices linking payoffs from firms that will substantially affect subsequent returns. The numbers presented in the table make it relatively easy to see the effects of various treatments of firms disappearing. The choice of December 1983 as a starting date is somewhat arbitrary. The first personal computer generally is acknowledged to be the MITS Altair introduced in 1974 [Ceruzzi 1998, p. 226], but the introduction of the IBM PC in August 1981 and its subsequent commercialization seem to us to be more important for the values of firms traded on organized exchanges.

These data show dramatically different annual returns across the firms, and the returns for the whole period vary substantially. The highest average annual return is 35.0 percent per year for Dell and the lowest is -77.7 percent per year for Diversified Technologies, which does not appear in the CRSP files after February 1985. Dell, Zeos, NCR, Compaq and Apple have positive returns that stand out. The average return across stocks in Table 1, though, is an abysmal -9.1 percent per year, and this is for a period when the return for the CRSP value weighted and equally weighted indexes for all firms are 12.2 and 12.9 percent per year respectively. A cursory look at these numbers and the average returns suggests that these stocks have quite low returns.

A somewhat different view appears, though, from looking at the cumulative values from a dollar invested in each firm for the whole period with any dividends reinvested. The table shows, for example, that one dollar invested in Dell in June 1988 has a cumulative value of $\$ 256.92$ in December 2006. A dollar invested in Hewlett Packard in December 1983 has a value of $\$ 12.22$ in December 2006. For 1983 through 2006, the average across firms of the cumulative values from investing in these stocks is $\$ 14.53$, above the value-weighted CRSP index's payoff of $\$ 14.05$ although less than the equally weighted CRSP index's payoff of $\$ 16.16$. The average cumulative values 
for subperiods show that a dollar invested in a portfolio of these firms provided payoffs similar to or greater than the CRSP indexes in all periods except 1987 to 1991 and 1999 to 2003.

These cumulative values appear to tell a different story than the returns. The average of the cumulative values for the whole period for all stocks in companies producing PCs is $\$ 14.53$ which is greater than the initial investment of a dollar. This $\$ 14.53$ can be interpreted as the amount received as a result of a strategy of investing $1 / 24$ of a dollar in each of these PC firms when it enters our data set and selling at the price at the end of the last month for which we have data on the firm. The assumed return on the funds is zero when not invested in a PC company. The average annual proportional return is -9.1 percent per year and the average of the cumulative values for the $\mathrm{PC}$ companies is $\$ 14.53$. How can a negative average return be consistent with a final payoff over fourteen times greater than the initial investment? ${ }^{4}$

\section{Payoffs and Expected Returns}

The seeming contradiction between this higher payoff from investing in the PC producers and the negative average returns is due to the difference between averaging the returns and averaging the cumulative values. The mean of the returns is

$$
\mu_{r}=\frac{\sum_{i=1}^{N}\left(V_{i}^{\left(1 / T_{i}\right)}-1\right)}{N}
$$

where $V_{i}$ is the cumulative value for firm $i, i=1, \ldots, N, T_{i}$ is the number of periods for which we have returns for firm $i, \mu_{r}$ is the mean return and we have used the fact that the initial value is one. The mean of the cumulative values is

$$
\mu_{F}=\frac{\sum_{i=1}^{N} V_{i}}{N}
$$

\footnotetext{
${ }^{4}$ Both averages are across firms.
} 
These two averages need not produce similar rankings and equation (1) can have a negative solution while equation (2) has a solution greater than unity. The basic problem is the nonlinear operation of taking a root to calculate the average annual return for each firm.

Agents' preferences are over final consumption in any standard economic model, so the cumulative values are more pertinent than average returns for comparing payoffs relative to the market. Furthermore, by Jensen's inequality, equation (1) will be less than the expected return. In our case, this underestimation of the expected return turns out to be quite large.

Besides this nonlinear difference between the averages, there is another problem with the average annual return across firms. In that computation, each firm is weighted the same whether it exists for one year or for all 23 years. In effect, there is a reverse survivor bias, an expiring bias. The return per year for the few years that some firms exist has the same weight in (1) as the return per year for firms that exist for the whole period. If one is interested in the expected return in any given month, the average returns across firms conditional on their existence would weight each firm's average return for the months that it exists by the number of months that the firm is in existence relative to other firms.

What is a better way of estimating the expected return from the stocks? We suppose that the expected return is constant across stocks since the interesting estimate for our purpose is the distribution of returns not conditional on any information about the individual firms. For simplicity, we also suppose that the expected value and volatility are constant over time with a log-normal distribution of returns. It is well known that a log-normal distribution of returns can cumulate into skewed distributions of values such as these in Table 1. It might seem that the assumption of log-normality is grossly inconsistent with the evidence for stock markets, but much of that evidence is for high-frequency time-series data conditional on prior returns. 
In contrast, we are estimating the expected return across firms for a typical period chosen at random, not a value for a specific period, say July 1992, conditional on prior returns. The issue for our estimates is whether the simple model is seriously at variance with the returns across firms, thereby suggesting that the estimated expected return is likely to be misleading. Results of Kolmogorov-Smirnov test and Bera-Jarque tests are reported in the tables with the estimates; these tests generally are consistent with the log-normal distribution being a reasonable characterization of the cumulative values.

This suggests a simple underlying price dynamic given by standard Brownian motion,

$$
d V(t) / V(t)=\mu d t+\sigma d B(t)
$$

where $V(t)$ is the cumulative value at $t, \mu$ is the expected return, $\sigma$ is the underlying volatility of the return and $B(t)$ is a standard Wiener process. Applying Ito's lemma,

$$
d \ln V(t)=\left(\mu-\frac{1}{2} \sigma^{2}\right) d t+\sigma d B(t)=\alpha d t+\sigma d B(t)
$$

These equations indicate that

$$
\mu=\alpha+(1 / 2) \sigma^{2}
$$

where $\alpha$ is the continuously compounded return. The maximum likelihood estimators of these parameters are well known [Tsay 2002; Gourieroux and Jasiak 2001; Campbell, Lo and MacKinlay 1996] and are given by

$$
\begin{aligned}
\widehat{\alpha} & =\frac{1}{T} \sum_{t=1}^{T} r_{t} \\
\widehat{\sigma}^{2} & =\frac{1}{T} \sum_{t=1}^{T}\left[r_{t}-\widehat{\alpha}\right]^{2} \\
\widehat{\mu} & =\widehat{\alpha}+(1 / 2) \widehat{\sigma}^{2},
\end{aligned}
$$

where $r_{t}=\Delta \ln V_{t}, T=\sum_{i=1}^{N} T_{i}$ and $t=1, \ldots, T$. The index $t$ runs all return-months, so that an observation is the log return for a month for a firm. 
We have data on returns monthly and the returns are most conveniently analyzed at annual rates. The diffusion equation is $d V(t) / V(t)=\mu h d t+\sigma \sqrt{h} d B(t)$ where $h$ is the time interval. For example, if returns and variances are measured at an annual frequency, data are available for 20 years and there are 240 observations because the data are equally spaced monthly values over the twenty years, then $h=20 / 240=$ 1/12. Data are available for different lengths of time for the firms. There are $n_{i}$ observations on firm $i$ over the time interval $T_{i}=T_{i}^{e}-T_{i}^{f}+1$, which implies that $T_{i}=n_{i} h$. The symbol $T_{i}^{f}$ denotes the first time period for which a return is available and the symbol $T_{i}^{e}$ denotes the ending time period for which a return is available.

The maximum likelihood estimators of the parameters are

$$
\begin{aligned}
\widehat{\alpha} & =\frac{\sum_{i=1}^{N} \sum_{t=T_{i}^{r}}^{T_{i}^{e}} r_{t}^{i}(h)}{h \sum_{i=1}^{N} n_{i}}=\frac{\sum_{i=1}^{N} \ln V_{T_{i}}^{i}}{h \sum_{i=1}^{N} n_{i}}=\sum_{i=1}^{N} w_{i} \ln V_{T_{i}}^{i} / T_{i} . \\
\widehat{\sigma}^{2} & =\frac{\sum_{i=1}^{N} \sum_{t=T_{i}^{r}}^{T_{i}^{e}}\left[r_{t}^{i}(h)-\widehat{\alpha} h\right]^{2}}{\sum_{i=1}^{N} n_{i}}
\end{aligned}
$$

where $r_{t}^{i}(h)$ denotes the return for firm $i$ at frequency $h$ and we use the fact that $\ln T_{i}^{f}=0$. The variance-covariance matrix for $\widehat{\alpha}$ and $\widehat{\sigma}^{2}$ is

$$
\operatorname{Var}\left[\begin{array}{cc}
\widehat{\alpha} & \widehat{\sigma}^{2}
\end{array}\right]^{\prime}=\left[\begin{array}{cc}
\frac{\sigma^{2}}{h \sum_{i=1}^{N} n_{i}} & 0 \\
0 & \frac{2 \sigma^{4}}{\sum_{i=1}^{N} n_{i}}
\end{array}\right]
$$

The estimator of $\widehat{\mu}$ is $\widehat{\mu}=\widehat{\alpha}+\widehat{\sigma}^{2} / 2$ and the variance-covariance matrix for $\widehat{\mu}$ and $\widehat{\sigma}^{2}$ is

$$
\operatorname{Var}\left[\begin{array}{cc}
\widehat{\mu} & \widehat{\sigma}^{2}
\end{array}\right]^{\prime}=\left[\begin{array}{cc}
\frac{\sigma^{2}}{h \sum_{i=1}^{N} n_{i}}+\frac{\sigma^{4}}{2 \sum_{i=1}^{N} n_{i}} & \frac{\sigma^{4}}{\sum_{i=1}^{N} n_{i}} \\
\frac{\sigma^{4}}{\sum_{i=1}^{N} n_{i}} & \frac{2 \sigma^{4}}{\sum_{i=1}^{N} n_{i}}
\end{array}\right] .
$$

Given this simple setup, the expected return is straightforward to compute. The mean of the log changes is -0.0301 per year and the maximum likelihood estimate of $\sigma^{2}$ is a quite high 0.3043 per year. ${ }^{5}$ The implied estimate of $\mu$ is 0.1220 . These numbers are summarized in the first row of Table 1.

\footnotetext{
${ }^{5}$ Using all of the daily data on stock prices would have no effect on the estimate of the average
} 
The last two columns in the first row of Table 1 also present Kolmogorov-Smirnov and Bera-Jarque test statistics for examining the adequacy of the log-normal distribution for characterizing the distribution of final cumulative values. The p-values of these tests are 0.15 and 0.78 , which suggests that the log-normal distribution is not extremely inconsistent with the data.

How does this expected return compare with the CRSP indexes for the same period? Using the values of the monthly equally-weighted CRSP index over the same period, we estimate a mean of the $\log$ changes $\alpha$ of 0.1210 per year and a volatility $\sigma^{2}$ of 0.0331 . The implied estimate of $\mu$ is 0.1375 per year. Using the values of the monthly value-weighted CRSP index over the same period, we estimate an expected return $\mu$ of 0.1265 per year.

Our estimates indicate an expected return for PC stocks somewhat less than the return for the market. The estimate of the expected return on stocks in PC firms is about 12.2 percent per year. For the same period, the estimate of the market expected return is about 13.8 percent for the equally-weighted CRSP index and 12.6 percent per year for the value-weighted CRSP index. It is quite possible that investors in PC firms received less than the risk-adjusted return on alternative investments. Many firms in the PC industry did badly and some firms disappeared; the distribution of cumulative values across firms shows a high probability of loss and some probability of a large gain. In the last section of the paper, we examine the returns from a portfolio of PC firms compared to returns from the market.

return. Using all of the daily data on stock prices would increase the precision of the estimate of the variance. We doubt that it would affect the estimated variance in the first one or two decimal places and it would make these computations non-comparable to the computations that are feasible with earlier industries. As a result, we use monthly prices from the CRSP files. 


\section{AIRLINES AND AIRPLANES}

Table 2 shows the distribution of returns across the airline and airplane manufacturing industries. This table covers December 1925 to December 1940. December 1925 is the start of the CRSP data, which is our source for these data. These are all of the identifiable airlines and airplane manufacturers in the CRSP data in this period. ${ }^{6}$ We use December 1940 as the last date to mitigate effects of World War II, which are likely to be extraordinary relative to the distribution of returns that investors have in mind before the War. These data also span the Great Depression. Making comparisons with the overall market ameliorates the effects of developments affecting all stocks' returns even if it does not completely suppress the effect of the Depression. We have data on both airlines and airplane manufacturing. We analyze airlines and airplane manufacturers separately because these two sets of firms are quite different even if they both arose from the commercialization of flying in heavier-than-air machines.

There is substantial dispersion in the distribution of cumulative values for the airline industry in Table 2. There are no very large payoffs on the order of magnitude of the PC industry though. Two firms - American Airlines and Eastern Airlines - have very high annual average returns, but these firms exist only for brief periods toward the end of the period. Four of the eleven airlines have cumulative values less than the initial investment of a dollar. The average final payoff across all airlines is $\$ 1.19$ from an initial dollar invested, which is greater than the initial amount invested but less than the payoff of $\$ 2.49$ from the equally-weighted CRSP index for the same period.

Over this period, the airplane manufacturing industry provides better returns for investors than the airline industry. Only one of the five manufacturing firms has

\footnotetext{
${ }^{6}$ Not all of the firms engaged exclusively in providing transportation services by plane. For example, Philadelphia Rapid Transit provided local transit service in Pennsylvania and provided airplane service between cities.
} 
a payoff less than the initial investment, and three of the five have annual returns from 16 to 20 percent. There is no evidence of any exceptional payoffs in airplane manufacturing on the order of those received by owners of Dell stock though, even though investors in Wright Aeronautical Aviation and Douglas Aircraft did well.

Returns from airlines and airplane manufacturing provide support for substantial dispersion in outcomes. At one extreme, an investor of $\$ 1$ in Wright Aeronautical in December 1925 received $\$ 9.67$ in December 1940. At the other extreme, an investor of $\$ 1$ in Philadelphia Rapid Transit received $\$ 0.07$ at the end of virtually the same period.

The expected return to an investor in airlines in this period is 0.1753 per year. The estimate of the mean of the log changes $\alpha$ is -0.0298 per year and the estimate of the volatility $\sigma^{2}$ is 0.4102 per year, figures comparable in magnitude to PCs. The expected return to an investor in airplane manufacturing is quite a bit higher, 0.3316 per year. This estimate is based on an estimated mean of the log changes $\alpha$ of 0.0837 per year and an estimated volatility $\sigma^{2}$ of 0.4957 per year.

For the CRSP indexes, the expected return is 0.1505 per year for the equallyweighted index and 0.0782 for the value-weighted index. The difference between these two different indexes reflects a higher average growth rate and higher volatility of the CRSP equally-weighted index.

The expected return from holding stock in an airline or airplane manufacturing firm is greater than the expected return from holding an equally-weighted or valueweighted market basket of stocks, contrary to the evidence for PCs.

\section{AUTOMOBILES}

Some investors in the automobile industry did enjoy extraordinary returns for part of the twentieth century. Table 3 shows that investors in two companies in particular did very well. One dollar invested in General Motors in 1912 was worth $\$ 12.72$ by 
1928. Investing the same amount in Packard in 1922 was worth $\$ 12.12$ by 1928 , which is even better because the period is less than half as long. ${ }^{7}$

Table 3 presents the 22 companies for which we have dividend and stock price information. The data are from contemporary periodicals. ${ }^{8}$ The returns for the whole period are from December 1912 to December 1928. The data start in 1912 because there is little information available on stock prices before 1912. The computations end in 1928 to avoid the effects of the stock market crash and the Great Depression.

How well does this sample of twenty firms represent the automobile industry over this same period? From 1902 until the end of 1927, 181 different firms produced automobiles for some period..$^{9}$ There was substantial turnover, with 88 firms producing automobiles in one year. ${ }^{10}$ Only 44 firms were producing automobiles by the end of 1927. The companies most left out of our sample are those whose stock did not trade publicly, which means that the firms in our sample generally are among the most prominent. An exception to this generalization is Ford Motor Company, which was closely held and whose stock did not trade on an organized exchange.

The cumulative values received by investors in GM and Packard are exceptional, not typical. Table 3 shows that the mean and median cumulative values for all companies are $\$ 3.550$ and $\$ 1.933$. These figures can be compared to those for the Cowles index for December 1912 to December 1928 [Cowles 1939]. The Cowles index is the best market index available for this period and is value weighted. The cumulative value for the Cowles index for 1912 to 1928 is $\$ 5.918$, which is greater than either the mean or median for the automobile industry. Only seven of the 22 automobile

\footnotetext{
${ }^{7}$ Ford also paid high dividends, but its stock price is not available because the stock was closely held.

${ }^{8}$ The sources for this and other data are in the Data Appendix.

${ }^{9}$ Seltzer [1928, p. 65, Table 5] shows the number of automobile producers and the number of firms entering and exiting for each year from the end of 1902 to 1926.

${ }^{10}$ This maximum of 88 firms producing automobiles occurred in 1921.
} 
manufacturers have cumulative values as high as the Cowles index. In over two-thirds of these companies, $\$ 1$ invested earned a payoff less than $\$ 5.92$, the value of the same investment in the overall market over this period.

The returns in this table vary widely. The highest annual returns are 73.1 percent per year for Stutz for the brief period from September 1916 to March 1920 and 50.7 percent per year for Packard from November 1922 to December 1928. General Motors has an annual average return of 17.2 percent for the 16 year period. The lowest annual average return is -15.4 percent for Nash Motor for July 1922 to December 1928.

The expected return to an investor in this sample of automobile companies in this period is a rather high 0.3101 per year. As for the other industries, a relatively high volatility is an important component of this estimate: the estimate of the volatility $\sigma^{2}$ is 0.4180 per year, although the average log change is a non-negligible 0.1011 per year. This expected return of 0.3101 is similar to the expected return of 0.3316 for airplane manufacturers. The expected return to an investor in the Cowles index over the same period is 0.1207 per year, quite a bit lower than the return for automobile companies.

\section{RAILROADS}

The railroad industry expanded rapidly, fueled at least in part by stock offerings. Table 4 presents our data for railroads traded on the New York Stock Exchange (NYSE). The data on stock prices and dividends are from contemporary periodicals. We compare railroad returns to returns based on the equally-weighted index with

dividends reinvested which has been compiled by Goetzmann, Ibbotson and Peng [2001].

There is a wide dispersion in proportional returns across firms, ranging from a high of 51.6 percent per year to a low of -73.9 percent per year. The estimated expected return for an investor in these railroads is 0.0982 per year. This expected return 
is significantly lower than in the later industries examined in this paper, and the volatility of 0.1583 percent is roughly half these other industries' volatilities.

Goetzmann, Ibbotson and Peng [2001] construct an equally-weighted market index for the NYSE that can be used to estimate the expected return for the overall markets. For the period covered by the NYSE railroads, 1850 to 1870, the estimated expected return on this index is 0.1831 per year. This expected return is due mostly to the mean $\log$ return of 0.1416 per year with a smaller contribution by the volatility of 0.0830. The expected return on the market is twice the expected return for railroad stocks.

\section{THE TELEGRAPH INDUSTRY}

The telegraph has been cited as the forerunner of the Internet, e.g. by Standage [1999]. The telegraph network is a network in which interconnections are paramount, interconnections that ultimately were associated with dramatic consolidation into the Western Union [Thompson 1947]. The telegraph had dramatic effects on the U.S. economy in the 1830s and later [Garbade and Silber 1978], but an extensive search of New York periodicals and historical monographs did not turn up a price for a trade on an exchange before August 18, 1865. Virtually all of the consolidation in the telegraph industry into the Western Union monopoly had occurred by 1865 , so this is too late for an analysis of the distribution of returns across firms. We do have sufficient information to calculate returns for Western Union. We also have evidence on dividends, which were more important in the middle 1800s than in the late 1900s [Baskin and Miranti 1997]. These dividends suggest that some investors in firms besides Western Union also did quite well.

Western Union stockholders clearly did well. A dollar invested in Western Union at incorporation in April 1851 was worth $\$ 1,816.75$ at the end of $1865 .{ }^{11}$ This is an

\footnotetext{
${ }^{11}$ Western Union did not pay cash dividends until the 1860 s, so this simplifies the calculations.
} 
annual average proportional return of 28 percent per year for almost 14 years. While not quite as spectacular as Dell's return of 35 percent per year, 28 percent is quite high relative to market returns in this period. What did investors in other firms receive?

Available data indicate that investors in some telegraph companies received substantial returns. Nontrivial dividends were a substantial part of those returns. The Magnetic Telegraph Company paid 12 percent "quite regularly". ${ }^{2}$ The Atlantic \& Ohio Telegraph Company paid a dividend of 18 percent shortly after incorporation and generally 12 percent per year afterwards. ${ }^{13}$ The Pittsburgh, Cincinnati \& Louisville Telegraph Company paid a dividend of 11 percent in the year in which it was incorporated and generally 12 percent per year thereafter. ${ }^{14}$ These high dividend rates relative to par value do not imply high dividend rates relative to market value, but the common complaint that stock prices generally were less than par value suggests dividend rates relative to market value were even higher. ${ }^{15}$ While it is likely that

We assume that the reinvestment of cash dividends occurs at the par value. The par value is $\$ 50$ and the price is $\$ 51$ at the end of 1865 .

${ }^{12}$ The Magnetic Telegraph Company built a line from New York to Philadelphia in 1845. Magnetic was acquired by American Telegraph Company shortly after October 1859. Magnetic Telegraph Company's dividend payments in early years on the par value of stock were 1848, 6 percent; 1849, 9 percent; 1850 and 1851, 2 percent; 1852, 9 percent; 1853 and 1854, 13 percent; and 12 percent was "paid quite regularly" thereafter. [Thompson 1947, p. 42, p. 331, p. 195].

${ }^{13}$ The Atlantic \& Ohio Telegraph Company was incorporated in March 1847 and later acquired. During its life, the Atlantic \& Ohio paid dividends of 18 percent in 1848 and generally 3 percent per quarter thereafter [Thompson 1947, p. 99, p. 296, p. 137].

${ }^{14}$ The Pittsburgh, Cincinnati \& Louisville Telegraph Company also was established in February 1848 and was consolidated with the Western Union in 1856. During its existence, this line paid dividends of 11 percent in 1848 and generally 3 percent per quarter thereafter. [Thompson 1947, p. 121, pp. 292-93, p. 137].

${ }^{15}$ Issuing sufficient stock that the price was noticeably less than the par value was called "watering" the stock, which meant watering down the value of the stock by issuing more shares than suggested 
these dividends are mentioned because they are startling and not everyday values, an inference that some firms had high returns seems well supported. Returns were not uniformly high; Thompson [1947] documents failed telegraph lines.

These dividend rates are high compared to contemporaneous interest rates on government securities, which are on the order of five and six percent per year. [Dwyer, Hafer and Weber 1999]. These dividend returns also are high relative to the total returns on the market index for this period [Goetzmann, Ibbotson and Peng 2001].

In sum, some telegraph firms clearly had high returns. A precise estimate of the expected return is for a typical firm is not possible with the available data, but the available evidence does not point to a low expected return for investors in telegraphs.

\section{PORTFOLIOS OF STOCKS IN THESE NEW INDUSTRIES}

Given the high expected return and the high volatility of returns, it is not obvious whether portfolios of stocks in these industries would be attractive portfolios. We construct an equally weighted portfolio for each industry. This is not a realizable portfolio for a representative investor in the sense that not all investors can hold this portfolio in equilibrium, but market value weights are not available for most of the industries.

The Sharpe ratio is an obvious way to examine the attractiveness of these portfolios. It is clear that these firms provide much more volatile payoffs than holding the overall market, and in general, this higher volatility must be compensated by a higher portfolio return. What is the risk-return tradeoff comparing the industry and the overall market? If the risk-return tradeoff is better for the overall market than for the less diversified industry portfolio, then clearly holding the market dominates a portfolios of stocks in these industries. The Sharpe ratio measures the excess return by the par value. While an automatic inference from railroads to telegraphs clearly is unwarranted, railroad stock generally traded at less than par value even with substantial dividends. 
over the risk-free rate per unit of risk. The Sharpe ratio for a portfolio of firms in an industry can be compared to the Sharpe ratio for the market portfolio. The Sharpe ratio $(S R)$ is estimated by

$$
S R=\frac{\widehat{\mu}_{p}-\mu^{f}}{\widehat{\sigma}_{p}}
$$

where $\widehat{\mu}_{p}$ is the estimated annual expected return on a portfolio of stocks, $\widehat{\sigma}_{p}$ is the estimated standard deviation of the expected return and $\mu^{f}$ is the average annual return for a one-period risk-free asset.

Table 5 presents the Sharpe ratios for all the industries. The Sharpe ratio for the industry portfolio is less than the Sharpe ratio for the overall market in the same period for all industries except for airplane manufacturing. In the context of CAPM, this means that the market portfolio dominates the industry portfolio given the possibility of borrowing or lending unlimited amounts at the risk-free rate.

This does not deny, of course, that a prudent investor would hold at least some of these stocks as part of a market portfolio.

\section{SUMMARY AND CONCLUSION}

Adjusted for risk, expected returns are not particularly high for firms in new industries.

While investors generally are averse to risk, many interpret prices of stocks associated with the Internet as being inconsistent with traditional asset pricing models. Some have interpreted the behavior of prices in new industries as being consistent with bubbles in those industries.

Our evidence is consistent with new industries having distributions of payoffs across firms that are highly skewed. In this sense, new industries are similar to lotteries. As is well known though, this can be quite consistent with a log-normal distribution and our data across firms generally are consistent with a log-normal distribution of the 
cumulative values across firms.

Our evidence uniformly indicates that the expected return to owners of traded stock in new industries is positive and substantial. This is consistent with the proposition that investors receive expected returns that can be interpreted as compensation for the risk they bear.

The Sharpe ratios for these industries, though, indicate that a portfolio of stocks in these new industries is dominated by the market portfolio. It pays to hold stocks in new industries, but no more or less than it pays to hold other stocks. 


\section{REFERENCES}

Baskin, Jonathon Barron, and Paul J. Miranti, Jr. 1997. A History of Corporate Finance. Cambridge: Cambridge University Press.

Blumberg Capital. 1999. "MonkeyDex Apes Greenspan on Net Stocks." At http://www.blumbergcapital.com/press/story_11.htm.

Campbell, John Y., Andrew W. Lo and A. Craig MacKinlay. 1996. The Econometrics of Financial Markets. Princeton: Princeton University Press.

Ceruzzi, Paul E. 1998. A History of Modern Computing. Cambridge: The MIT Press.

Cowles 3rd, Alfred. 1939. Common-Stock Indexes. Second edition. Bloomington, Indiana: Principia Press, Inc.

Cochrane, John H. 2005. "The Risk and Return of Venture Capital." Journal of Financial Economics 75 (January), 3-52.

Dwyer, Jr., Gerald P., R. W. Hafer and Warren E. Weber. 1999. "Weekly U.S. and State Bond Prices." Historical Methods 32 Winter, 37-42.

Economist. 2000. "Bubble.com." Economist 356 (September 23), 19-21.

Fama, Eugene F., and Kenneth R. French. 2001. "Newly Listed Firms: Fundamentals, Survival Rates, and Returns." Unpublished paper, University of Chicago.

Garbade, Kenneth D., and William L. Silber. 1978. "Technology, Communication and the Performance of Financial Markets." Journal of Finance 33 (June), $819-32$.

Goetzmann, William N., Roger G. Ibbotson, and Liang Peng. 2001. "A New Historical Database for the NYSE 1815 to 1925: Performance and Predictability." Journal of Financial Markets 4 (January), 1-32. 
Gompers, Paul A., and Josh Lerner. 2003. "The Really Long-Run Performance of Initial Public Offerings: The Pre-Nasdaq Evidence." Journal of Finance 58 (August), 1355-92.

Gourieroux, Christian, and Joann Jasiak. 2001. Financial Econometrics. Princeton: Princeton University Press.

Hand, John R. M. 2001. "The Role of Book Income, Web Traffic, and Supply and Demand in the Pricing of U.S. Internet Stocks." European Finance Review 5 (3), 295-317.

Hof, Robert D., and Steve Hamm. 2002. "How E-Biz Rose, Fell, and Will Rise Anew." Business Week (May 13), 64-72.

Jensen, Michael C. 1993. "The Modern Industrial Revolution, Exit, and the Failure of Internal Control Systems." Journal of Finance 48 (July), 831-80.

Mandel, Michael J. 1999. "The Internet Economy." Business Week Issue 3617 (February 22$), 30-32$.

Nairn, Alasdair. 2002. Engines That Move Markets: Technology Investing from Railroads to the Internet and Beyond. New York: John Wiley \& Sons, Inc.

Pástor, Luboš, and Pietro Veronesi. 2005. "Technological Revolutions and Stock Prices." Unpublished paper, University of Chicago.

Seltzer, Lawrence H. 1928. A Financial History of the American Automobile Industry. Boston: Houghton Mifflin Company.

Standage, Thomas. 1999. The Victorian Internet. New York: Berkley Books.

Thompson, Robert L. 1947. Wiring a Continent: The History of the Telegraph in the United States, 1832-1866. Princeton, N.J.: Princeton University Press. 
Tsay, Ruey. 2002. Analysis of Financial Time Series. New York: John Wiley \& Sons, Inc.

Weiman, David F., and Richard C. Levin. 1994. "Preying for Monopoly? The Case of Southern Bell Telephone Company, 1894-1912. Journal of Political Economy 102 (February), 103-26. 
Table 1.

Personal Computer Companies and Stock Cumulative Values

December 1983 through December 2006

Individual Companies

\begin{tabular}{|c|c|c|c|c|c|c|c|c|c|c|}
\hline $\begin{array}{l}\text { Expected Return for } \\
\text { Personal Computer Firms }\end{array}$ & Mean Log Return & \multicolumn{2}{|r|}{ Variance of Log Return } & \multicolumn{2}{|c|}{$\begin{array}{c}\text { Expected Return for } \\
\text { CRSP Value-Weighted } \\
\text { Index }\end{array}$} & \multicolumn{2}{|c|}{$\begin{array}{l}\text { Expected Return for } \\
\text { CRSP Equally-weighted } \\
\text { Index }\end{array}$} & $\begin{array}{c}\text { Kolmogorov-Smirnov } \\
\text { Test }\end{array}$ & \multicolumn{2}{|c|}{ Bera-Jarque Test } \\
\hline \multirow[t]{3}{*}{$\begin{array}{l}0.1220 \\
0.0318\end{array}$} & $\begin{array}{c}-0.0301 \\
0.0316\end{array}$ & \multicolumn{2}{|r|}{$\begin{array}{c}0.3043 \\
0.2908 \quad 0.3188\end{array}$} & \multicolumn{2}{|c|}{$\begin{array}{l}0.1265 \\
0.0370\end{array}$} & \multicolumn{2}{|l|}{$\begin{array}{l}0.1375 \\
0.0441\end{array}$} & $\begin{array}{c}0.0843 \\
(0.1500)\end{array}$ & \multicolumn{2}{|c|}{$\begin{array}{c}0.5066 \\
(0.7762)\end{array}$} \\
\hline & \multicolumn{2}{|l|}{ Date } & \multirow[b]{2}{*}{ Annual Return } & \multicolumn{5}{|c|}{ Cumulative Value (\$) } & \multirow[b]{2}{*}{ 1999-2003 } & \multirow[b]{2}{*}{ 2003-2006 } \\
\hline & First & Last & & Entire Period & 1983-1987 & 1987-1991 & 1991-1995 & 1995-1999 & & \\
\hline Average & & & -0.0907 & 14.5331 & 1.5872 & 0.9754 & 1.7475 & 5.8287 & 0.6201 & 1.8914 \\
\hline Median & & & -0.0108 & 0.8505 & 1.3499 & 0.7171 & 1.1606 & 2.5521 & 0.4650 & 0.7384 \\
\hline Standard Deviation & & & 0.2779 & 52.2216 & 1.3452 & 1.0509 & 1.5724 & 11.7987 & 0.4913 & 2.7104 \\
\hline CRSP Value-Weighted Index & & & 0.1218 & 14.0473 & 1.5952 & 1.8950 & 1.6386 & 2.4189 & 0.8319 & 1.4094 \\
\hline CRSP Equal-Weighted Index & & & 0.1286 & 16.1592 & 1.0976 & 1.5790 & 1.9894 & 1.8403 & 1.6681 & 1.5268 \\
\hline \multicolumn{11}{|l|}{ Company } \\
\hline Dell Computer Corporation & Jun-88 & & 0.3498 & 256.9216 & & 2.7333 & 4.0537 & 47.1336 & 0.6663 & 0.7384 \\
\hline Zeos International & Sep-89 & Mar-95 & 0.2075 & 2.8209 & & 4.2985 & 0.6562 & & & \\
\hline NCR Corporation & & Aug-91 & 0.1997 & 4.0392 & 2.1672 & 1.8638 & & & & \\
\hline Compaq Computer & & Apr-02 & 0.1916 & 24.8841 & 4.4300 & 0.9526 & 5.4597 & 2.8356 & 0.3809 & \\
\hline Apple Computers Incorporated & & & 0.1602 & 30.5241 & 3.4636 & 1.3962 & 0.5929 & 3.2255 & 0.4157 & 7.9401 \\
\hline Canon Incorporated & & Dec-97 & 0.1207 & 4.9291 & 1.2977 & 1.7874 & 1.6478 & 1.2896 & & \\
\hline Hewlett Packard Company & & & 0.1150 & 12.2241 & 1.4040 & 1.0121 & 3.0823 & 2.8152 & 0.5328 & 1.8608 \\
\hline IBM & & & 0.0749 & 5.2609 & 1.0784 & 0.9141 & 1.1524 & 4.8691 & 0.8803 & 1.0804 \\
\hline Digital Equipment Corporation & & May- & 0.0300 & 1.5313 & 3.7500 & 0.4093 & 1.1606 & 0.8597 & & \\
\hline Advanced Logic Research & Apr-90 & Jun-97 & 0.0204 & 1.1557 & & 0.7170 & 0.6316 & 2.5521 & & \\
\hline NEC Corporation & & & -0.0003 & 0.9932 & 2.6366 & 0.6730 & 1.3167 & 2.0516 & 0.3164 & 0.6548 \\
\hline Inmac Corporation & Oct-86 & Dec-95 & -0.0004 & 0.9962 & 1.4020 & 0.1921 & 3.7000 & & & \\
\hline Unisys Corporation & & & -0.0211 & 0.6125 & 2.3282 & 0.1384 & 1.3333 & 5.8068 & 0.4650 & 0.5280 \\
\hline
\end{tabular}

Table 1 Continued on Next Page 
Table 1.

Personal Computer Companies and Stock Cumulative Values

1983 through 2006

Individual Companies

\begin{tabular}{|c|c|c|c|c|c|c|c|c|c|c|}
\hline \multirow[t]{2}{*}{ Company } & \multicolumn{2}{|c|}{ Date } & \multirow[b]{2}{*}{ Annual Return } & \multirow[b]{2}{*}{ Entire Period } & \multicolumn{4}{|c|}{ Cumulative Value (\$) } & \multirow[b]{2}{*}{$1999-2003$} & \multirow[b]{2}{*}{ 2003-2006 } \\
\hline & First & Last & & & 1983-1987 & $1987-1991$ & 1991-1995 & 1995-1999 & & \\
\hline Intergraph Corporation & & Sep-00 & -0.0571 & 0.3734 & 1.2857 & 0.7172 & 0.8873 & 0.2976 & 1.5333 & \\
\hline ACT Networks Incorporated & May-95 & Jul-00 & -0.0647 & 0.7078 & & & 0.8247 & 0.5866 & 1.4631 & \\
\hline Gateway Incorporated & Dec-93 & & -0.0663 & 0.4097 & & & 1.2484 & 11.7653 & 0.0638 & 0.4370 \\
\hline Televideo Systems & & Mar-99 & -0.2467 & 0.0133 & 0.0748 & 0.1316 & 4.4000 & 0.3068 & & \\
\hline Compudyne Corporation & & Feb-91 & -0.3174 & 0.0648 & 2.1296 & 0.0304 & & & & \\
\hline Micron Electronics & Apr-95 & Jul-01 & -0.3306 & 0.0814 & & & 0.7611 & 1.0349 & 0.1034 & \\
\hline Tandon Corporation & & Feb-93 & -0.3800 & 0.0125 & 0.0844 & 0.8148 & 0.1818 & & & \\
\hline Wells American Corporation & & Nov-90 & -0.4494 & 0.0170 & 0.1864 & 0.0909 & & & & \\
\hline CPT Corporation & & Jul-90 & -0.4615 & 0.0170 & 0.1456 & 0.1167 & & & & \\
\hline Everex System Incorporated & Jul-87 & Dec-92 & -0.4746 & 0.0306 & 0.5306 & 0.5192 & 0.1111 & & & \\
\hline Diversified Technologies & & Feb-85 & -0.7767 & 0.1739 & 0.1739 & & & & & \\
\hline
\end{tabular}

\section{Notes:}

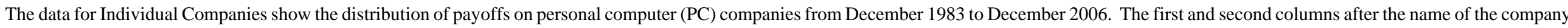

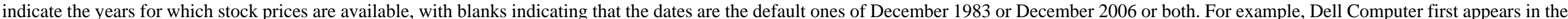

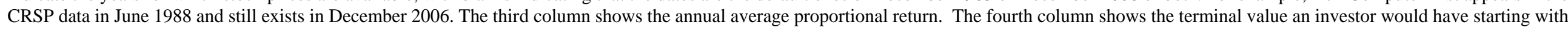

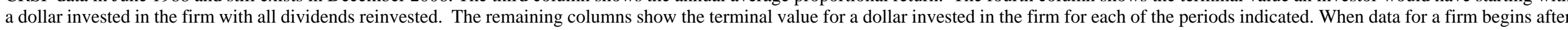

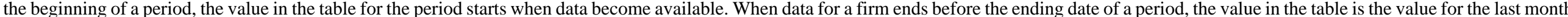

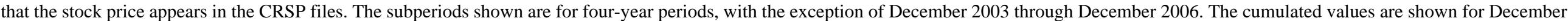
1999 through December 2003 as well as for December 2003 through December 2006, which makes it easy to see the effects of the crash in prices in 2000.

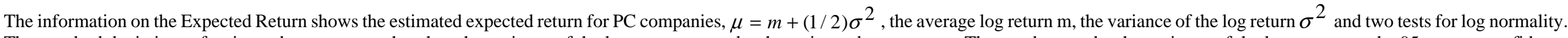

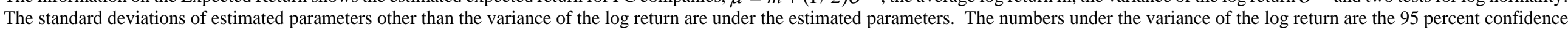

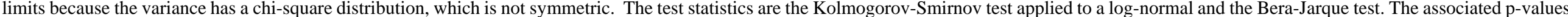

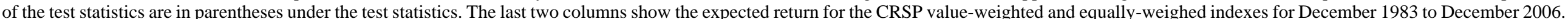


Table 2.

Airline and Airplane Companies and Stock Cumulative Values

December 1925 through December 1940

Individual Companies

\begin{tabular}{|c|c|c|c|c|c|c|c|}
\hline Industry & $\begin{array}{l}\text { Expected } \\
\text { Return }\end{array}$ & Mean Log Return & $\begin{array}{c}\text { Variance of Log } \\
\text { Return }\end{array}$ & $\begin{array}{c}\text { Expected Return for } \\
\text { CRSP Value-Weighted } \\
\text { Index }\end{array}$ & $\begin{array}{c}\text { Expected Return for } \\
\text { CRSP Equally-weighted } \\
\text { Index } \\
\end{array}$ & $\begin{array}{l}\text { Kolmogorov- } \\
\text { Smirnov Test }\end{array}$ & Bera-Jarque Test \\
\hline \multirow[t]{2}{*}{ Airlines } & 0.1753 & -0.0298 & 0.4102 & 0.0782 & 0.1505 & 0.2287 & 2.8597 \\
\hline & 0.0759 & 0.0752 & $0.3742 \quad 0.4517$ & 0.0805 & 0.1098 & $(0.1046)$ & $(0.2393)$ \\
\hline Airplane & 0.3315 & 0.0837 & 0.4957 & 0.0782 & 0.1505 & 0.2635 & 0.5994 \\
\hline Manufacturers & 0.0980 & 0.0970 & $0.4453 \quad 0.5551$ & 0.0805 & 0.1098 & $(0.1500)$ & $(0.7410)$ \\
\hline
\end{tabular}

\begin{tabular}{|c|c|c|c|c|c|c|c|c|}
\hline & \multicolumn{2}{|c|}{ Date } & \multirow[b]{2}{*}{ Annual Return } & \multicolumn{5}{|c|}{ Cumulative Value (\$) } \\
\hline & First & Last & & Entire Period & $1925-1928$ & $1928-1932$ & 1932-1936 & 1936-1940 \\
\hline CRSP Value-Weighted Index & & & 0.0302 & 1.5620 & 2.0301 & 0.3087 & 3.1500 & 0.7914 \\
\hline CRSP Equal-Weighted Index & & & 0.0626 & 2.4868 & 1.8783 & 0.2614 & 7.0284 & 0.7208 \\
\hline Average & & & 0.0523 & 1.1935 & 1.1891 & 0.3797 & 2.3109 & 1.3070 \\
\hline Median & & & 0.0138 & 1.1613 & 1.1891 & 0.1711 & 2.2062 & 1.1798 \\
\hline Standard Deviation & & & 0.2845 & 0.8004 & & 0.5288 & 1.0343 & 0.6557 \\
\hline \multicolumn{9}{|l|}{ Airline Companies } \\
\hline American Airlines Incorporated & Jun-39 & & 0.6878 & 2.1926 & & & & 2.1926 \\
\hline Eastern Airlines Incorporated & Nov-38 & & 0.5053 & 2.3443 & & & & 2.3443 \\
\hline Transcontinental and Western Air & Mar-35 & & 0.1536 & 2.2742 & & & 2.9786 & 0.7635 \\
\hline Consolidated Aircraft Incorporated & Jul-37 & & 0.0883 & 1.3351 & & & & 1.3351 \\
\hline National Aviation Corporation & Dec-33 & & 0.0286 & 1.2185 & & & 1.4852 & 0.8205 \\
\hline Aviation Corporation & Jan-30 & & 0.0138 & 1.1613 & & 1.3171 & 1.1429 & 0.7715 \\
\hline Pan American Airways & Dec-38 & & 0.0122 & 1.0245 & & & & 1.0245 \\
\hline United Aircraft \& Transportation & May-29 & & -0.0300 & 0.7027 & & 0.2291 & 1.7171 & 1.7864 \\
\hline Bendix Aviation Corporation & May-29 & & -0.0381 & 0.6376 & & 0.1468 & 2.6954 & 1.6116 \\
\hline Philadelphia Rapid Transit & & Oct-39 & -0.1782 & 0.0663 & 1.1891 & 0.0345 & 3.8460 & 0.4200 \\
\hline National Air Transport & May-29 & Mar-32 & -0.4638 & 0.1711 & & 0.1711 & & \\
\hline
\end{tabular}


Table 2 (Cont'd).

Airline and Airplane Companies and Stock Cumulative Values

1925 through 1940

\begin{tabular}{|c|c|c|c|c|c|c|c|c|}
\hline & \multicolumn{2}{|c|}{ Date } & \multirow[b]{2}{*}{ Annual Return } & \multicolumn{5}{|c|}{ Cumulative Value (\$) } \\
\hline & First & Last & & Entire Period & 1925-1928 & 1928-1932 & 1932-1936 & 1936-1940 \\
\hline Average & & & 0.1091 & 4.2026 & 11.4176 & 0.3008 & 6.2584 & 1.1456 \\
\hline Median & & & 0.1633 & 2.9207 & 11.4176 & 0.2561 & 4.5082 & 1.2558 \\
\hline Standard Deviation & & & 0.1203 & 3.6096 & & 0.2735 & 3.8061 & 0.3434 \\
\hline \multicolumn{9}{|l|}{ Airplane Manufacturers } \\
\hline Douglas Aircraft Incorporated & Jun-31 & & 0.2015 & 5.7217 & & 0.6192 & 7.3578 & 1.2558 \\
\hline Boeing Airplane Corporation & Sep-34 & & 0.1871 & 2.9207 & & & 4.5082 & 0.6479 \\
\hline Wright Aeronautical Aviation & & & 0.1633 & 9.6682 & 11.4176 & 0.0719 & 12.4405 & 0.9466 \\
\hline North American Aviation & Apr-30 & & 0.0838 & 2.3591 & & 0.4386 & 3.7760 & 1.4245 \\
\hline Curtiss Aeroplane \& & Aug-29 & & -0.0900 & 0.3432 & & 0.0736 & 3.2098 & 1.4529 \\
\hline Manufacturing & & & & & & & & \\
\hline
\end{tabular}

Note:

This table shows the distribution of payoffs on airlines and airplane manufacturers from December 1925 through December 1940. The notes to Table 1 explain the layout of the table. 
Table 3.

Automobile Companies and Stock Cumulative Values

1912 through 1928

Individual Companies

\begin{tabular}{|c|c|c|c|c|c|c|c|c|}
\hline \multirow{3}{*}{$\begin{array}{c}\begin{array}{c}\text { Expected Return for } \\
\text { Automobile Firms }\end{array} \\
\begin{array}{c}0.3101 \\
0.0496\end{array}\end{array}$} & Mean Log Return & \multicolumn{2}{|c|}{ Variance of Log Return } & $\begin{array}{l}\text { Expected Return for } \\
\text { Cowles Index }\end{array}$ & \multicolumn{2}{|c|}{ Kolmogorov-Smirnov Test } & \multicolumn{2}{|c|}{ Bera-Jarque Test } \\
\hline & \multirow{2}{*}{$\begin{array}{l}0.1011 \\
0.0492\end{array}$} & \multicolumn{2}{|c|}{0.4180} & 0.1207 & \multirow{2}{*}{\multicolumn{2}{|c|}{$\begin{array}{c}0.1251 \\
(>0.1500)\end{array}$}} & \multirow{2}{*}{\multicolumn{2}{|c|}{$\begin{array}{c}1.5813 \\
(0.4535)\end{array}$}} \\
\hline & & & $6 \quad 0.4446$ & & & & & \\
\hline & \multicolumn{2}{|c|}{ Date } & & \multicolumn{5}{|c|}{ Cumulative Value (\$) } \\
\hline & First & Last & Annual & Entire Period & 1912-1916 & $1916-1920$ & 1920-1924 & $1924-1928$ \\
\hline Average & & & 0.1312 & 3.5504 & 3.2289 & 1.5418 & 2.5386 & 2.5093 \\
\hline Median & & & 0.1382 & 1.9327 & 1.0283 & 0.7686 & 1.5070 & 1.7403 \\
\hline Standard Deviation & & & 0.2072 & 3.8517 & 5.2102 & 2.9538 & 3.7492 & 2.5118 \\
\hline Cowles Value-Weighted Index & & & 0.1176 & 5.9183 & 1.3332 & 0.9218 & 1.8960 & 2.5399 \\
\hline \multicolumn{9}{|l|}{ Company } \\
\hline Stutz Motor Car Company & Sept. 1916 & Mar. 1920 & 0.7309 & 6.8222 & 0.6912 & 9.8704 & & \\
\hline Packard Motor Car Company & Nov. 1922 & & 0.5071 & 12.1249 & & & 1.0290 & 11.7829 \\
\hline Dodge Brothers & May 1925 & Nov. 1928 & 0.3037 & 2.5301 & & & & 2.5301 \\
\hline Hudson Motor & Jun. 1922 & & 0.2968 & 5.4148 & & & 2.0992 & 2.5795 \\
\hline Hupp Motor Car Company & Jan. 1920 & & 0.2717 & 8.5273 & & 0.7668 & 2.0112 & 5.5276 \\
\hline Maxwell Class B & Dec. 1914 & Jul. 1925 & 0.2152 & 7.8667 & 3.1666 & 0.0474 & 16.0006 & 3.2778 \\
\hline Reo Motor Car Company & Dec. 1927 & & 0.2118 & 1.2118 & & & & 1.2118 \\
\hline Maxwell Class A & Jun. 1921 & Jul. 1925 & 0.1875 & 2.0170 & & & 1.3788 & 1.4630 \\
\hline Continental Motors & Dec. 1922 & & 0.1728 & 2.6015 & & & 0.8487 & 3.0653 \\
\hline General Motors & & & 0.1723 & 12.7217 & 15.8767 & 0.0277 & 6.4856 & 4.4589 \\
\hline Gardner Motor & Apr. 1923 & & 0.1436 & 2.1392 & & & 0.5116 & 4.1819 \\
\hline Studebaker Corporation & & & 0.1382 & 7.9290 & 2.7949 & 0.7704 & 1.5070 & 2.4438 \\
\hline Chrysler Motor & Jul. 1925 & & 0.0847 & 1.3200 & & & & 1.3200 \\
\hline Jordan Motor Company & Mar. 1924 & & 0.0581 & 1.3075 & & & 1.9587 & 0.6675 \\
\hline White Motor Company Stock & Oct. 1916 & & 0.0556 & 1.9327 & 0.8893 & 1.0482 & 2.7470 & 0.7549 \\
\hline Pierce-Arrow Motor Car Company & Jun. 1917 & & -0.0129 & 0.8614 & & 0.6067 & 0.7038 & 2.0176 \\
\hline
\end{tabular}


Table 3 (Cont'd).

Automobile Companies and Stock Cumulative Values

1912 through 1928

\begin{tabular}{|c|c|c|c|c|c|c|c|c|}
\hline \multirow[t]{2}{*}{ Company } & \multicolumn{2}{|c|}{ Date } & \multirow[b]{2}{*}{ Annual } & \multicolumn{5}{|c|}{ Cumulative Value (\$) } \\
\hline & First & Last & & Entire Period & 1912-1916 & 1916-1920 & 1920-1924 & 1924-1928 \\
\hline Moon Motors & Aug. 1922 & & -0.0314 & 0.8169 & & & 2.2606 & 0.3613 \\
\hline Chandler Motor & Feb. 1916 & & -0.0385 & 0.6040 & 1.1674 & 1.0421 & 0.8411 & 0.5903 \\
\hline Paige-Detroit Motor Car Company & Apr. 1925 & Dec. 1927 & -0.0397 & 0.8976 & & & & 0.8976 \\
\hline Kelly-Springfield Motor Truck Co. & Mar. 1916 & & -0.0492 & 0.5255 & 0.8653 & 1.0500 & 0.4246 & 1.3624 \\
\hline Willys-Overland Motor Car Co. & Feb. 1915 & & -0.0574 & 0.4418 & 0.3801 & 0.1888 & 1.9091 & 3.2257 \\
\hline Peerless Truck and Motor & Oct. 1926 & & -0.1498 & 0.7036 & & & & 0.7035 \\
\hline Nash Motor & Jul. 1922 & & -0.1535 & 0.3432 & & & 0.4394 & 0.7809 \\
\hline
\end{tabular}

Note:

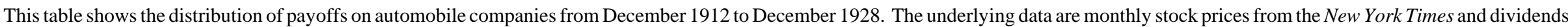
from Moody's. The notes to Table 1 explain the layout of the table. 
Table 4.

Railroads Traded on the New York Stock Exchange and Stock Cumulative Values Sept 1851-Dec 1870

Expected Returns

\begin{tabular}{|c|c|c|c|c|c|c|}
\hline $\begin{array}{l}\text { Expected Returns } \\
\text { for } \\
\text { NYSE Railroads }\end{array}$ & Mean Log Return & $\begin{array}{c}\text { Variance of Log } \\
\text { Return }\end{array}$ & $\begin{array}{l}\text { Expected Return for } \\
\text { Goetzmann et al. } \\
\text { Equally-Weighted Index }\end{array}$ & $\begin{array}{l}\text { Expected Return for } \\
\text { Goetzmann et al. Price- } \\
\text { Weighted Index }\end{array}$ & $\begin{array}{c}\text { Kolmogorov-Smirnov } \\
\text { Test }\end{array}$ & Bera-Jarque Test \\
\hline 0.0982 & 0.0190 & 0.1583 & 0.1831 & 0.0801 & 0.2191 & 84.2323 \\
\hline 0.0224 & 0.0222 & $0.1514 \quad 0.1656$ & 0.0662 & 0.0407 & $(<0.0100)$ & $(<0.0001)$ \\
\hline
\end{tabular}

\begin{tabular}{|c|c|c|c|c|c|c|}
\hline & Annual Return & Entire Period & $\underline{1851-1855}$ & $\underline{1855-1860}$ & $\underline{1860-1865}$ & $\underline{1865-1870}$ \\
\hline Goetzmann et al. Equal-Weighted Index (Annual Data) & 0.1522 & 14.7460 & 1.2600 & 3.3813 & 3.3170 & 1.0435 \\
\hline Goetzmann et al. Price-Weighted Index (Annual Data) & 0.0616 & 3.1119 & 1.1369 & 0.9520 & 2.5847 & 1.1124 \\
\hline Average & 0.0166 & 1.7414 & 1.0324 & 0.7151 & 3.5002 & 1.1100 \\
\hline Median & 0.0245 & 1.1644 & 1.0275 & 0.6827 & 2.0642 & 1.0611 \\
\hline Standard Deviation & 0.1945 & 2.4433 & 0.3164 & 0.4699 & 4.2539 & 0.4114 \\
\hline
\end{tabular}

Railroads Traded on the New York Stock Exchange and Stock Cumulative Values

Sept 1851-Dec 1870

Individual Companies

\begin{tabular}{|c|c|c|c|c|c|c|c|c|}
\hline \multirow[t]{2}{*}{ Company } & \multicolumn{2}{|c|}{ Date } & \multirow[b]{2}{*}{ Annual Return } & \multicolumn{5}{|c|}{ Cumulative Value (\$) } \\
\hline & First & Last & & Entire Period & 1851-1855 & $1855-1860$ & 1860-1865 & $1865-1870$ \\
\hline Milwaukee and Prairie Du Chien & Jul-61 & Feb-66 & 0.5162 & 6.7368 & & & 6.7368 & 1.0000 \\
\hline St. Louis, Alton and Terre Haute & Dec-62 & Apr-70 & 0.3609 & 9.5809 & & & 4.1097 & 2.3313 \\
\hline Albany and Schenectady & Oct-51 & Jun-53 & 0.2865 & 1.5218 & 1.5218 & & & \\
\hline Utica and Schenectady & & Jun-53 & 0.2522 & 1.4822 & 1.4822 & & & \\
\hline Rochester and Syracuse & & Jun-53 & 0.2480 & 1.4737 & 1.4737 & & & \\
\hline Rochester, Lockport and Niagra Falls & Apr-52 & May-53 & 0.2447 & 1.2676 & 1.2676 & & & \\
\hline New York and Harlem & Jan-56 & & 0.2071 & 16.5807 & & 0.9408 & 19.6552 & 0.8967 \\
\hline Pittsburg, Ft. Wayne and Chicago & Aug-62 & Aug-69 & 0.2068 & 3.7270 & & & 2.5982 & 1.4345 \\
\hline Long Island & & Jul-54 & 0.1696 & 1.5587 & 1.5587 & & & \\
\hline
\end{tabular}


Table 4.

Railroads Traded on the New York Stock Exchange and Stock Cumulative Values

Sept 1851-Dec 1870

Individual Companies

\begin{tabular}{|c|c|c|c|c|c|c|c|c|}
\hline \multirow[t]{2}{*}{ Company } & \multicolumn{2}{|c|}{$\underline{\text { Date }}$} & \multirow[b]{2}{*}{ Annual Return } & \multicolumn{5}{|c|}{ Cumulative Value (\$) } \\
\hline & First & Last & & Entire Period & 1851-1855 & $1855-1860$ & 1860-1865 & $1865-1870$ \\
\hline Chicago and Northwestern & Jan-63 & & 0.1644 & 3.3370 & & & 1.5652 & 2.1320 \\
\hline Chicago, Burlington and Quincy & Jan-60 & Dec-67 & 0.1520 & 3.0645 & & 1.6250 & 1.6113 & 1.1704 \\
\hline Milwaukee and St. Paul Preferred & Jan-68 & Dec-69 & 0.1477 & 1.3022 & & & & 1.3022 \\
\hline Reading & & Dec-55 & 0.1395 & 1.7417 & 1.7417 & & & \\
\hline Syracuse and Utica & & Apr-53 & 0.0828 & 1.1341 & 1.1341 & & & \\
\hline Cleveland and Pittsburg & Jan-53 & & 0.0818 & 4.0912 & 0.7129 & 0.3808 & 12.3036 & 1.2250 \\
\hline Hannibal and St. Joseph & Jan-68 & & 0.0764 & 1.2396 & & & & 1.2396 \\
\hline Milwaukee and St. Paul & Feb-66 & & 0.0707 & 1.3917 & & & & 1.3917 \\
\hline Stonington & & Nov-55 & 0.0530 & 1.2402 & 1.2402 & & & \\
\hline New York Central and Hudson River & Nov-69 & & 0.0516 & 1.0560 & & & & 1.0560 \\
\hline Chicago and Northwestern Preferred & Jan-68 & Dec-69 & 0.0495 & 1.0970 & & & & 1.0970 \\
\hline Pittsburg, Ft. Wayne and Chicago Guaranteed & Aug-69 & & 0.0493 & 1.0662 & & & & 1.0662 \\
\hline Delaware, Lackwanna and Western & Jan-60 & & 0.0473 & 1.6558 & & 1.4815 & 1.1343 & 0.9853 \\
\hline Chicago and Alton & Jul-63 & & 0.0454 & 1.3897 & & & 1.2678 & 1.0962 \\
\hline Hudson River & & Nov-69 & 0.0447 & 2.2143 & 0.4393 & 1.4634 & 2.4056 & 1.4319 \\
\hline Toledo, Wabash and Western & Feb-66 & & 0.0445 & 1.2344 & & & & 1.2344 \\
\hline New Jersey & Nov-51 & Dec-55 & 0.0380 & 1.1645 & 0.1645 & & & \\
\hline Galena and Chicago Union & Feb-53 & May-64 & 0.0272 & 1.3520 & 1.2020 & 0.5522 & 2.0370 & \\
\hline New York Central & May-53 & Nov-69 & 0.0262 & 1.5320 & 0.8236 & 0.8395 & 1.2614 & 1.7565 \\
\hline Illinois Central & Jan-53 & & 0.0259 & 1.5795 & 1.0290 & & 1.4871 & 1.0323 \\
\hline Illinois Central Scrip & Jan-56 & Sept-64 & 0.0253 & 1.2421 & & 0.7895 & 1.5733 & \\
\hline Chicago and Rock Island & May-54 & Jun-69 & 0.0237 & 1.4226 & 1.0267 & 0.6100 & 2.0914 & 1.0862 \\
\hline Michigan Southern & Dec-51 & Apr-55 & 0.0228 & 1.0779 & 1.0779 & & & \\
\hline New Haven and Hartford & Oct-51 & Oct-55 & 0.0188 & 1.0773 & 1.0773 & & & \\
\hline Sixth-Avenue & Dec-52 & Oct-55 & 0.0172 & 1.0494 & 1.0494 & & & \\
\hline Michigan Central & Feb-52 & & 0.0171 & 1.3760 & 1.0275 & 0.4866 & 2.2650 & 1.2150 \\
\hline Erie Railway & Jul-61 & & 0.0152 & 1.1530 & & & 4.0000 & 0.2883 \\
\hline Michigan Southern and Northern Indiana & May-55 & May-69 & 0.0113 & 1.1698 & 0.8979 & 0.1589 & 5.1466 & 1.5930 \\
\hline Cleveland and Toledo & Oct-53 & Mar-69 & 0.0111 & 1.1861 & 0.7917 & 0.4351 & 3.6290 & 0.9489 \\
\hline Philadelphia and Reading & Jan-56 & & 0.0103 & 1.1643 & & 0.4222 & 3.1195 & 0.8840 \\
\hline Morris and Essex & Jan-69 & & 0.0090 & 1.0172 & & & & 1.0172 \\
\hline North Indiana & Mar-52 & Apr-55 & -0.0044 & 0.9866 & 0.9867 & & & \\
\hline Cleveland, Columbus and Cincinnati & Dec-52 & Jun-68 & -0.0057 & 0.9157 & 0.8512 & 0.8610 & 1.5156 & 0.8244 \\
\hline New York and New Haven & & Jun-67 & -0.0120 & 0.8276 & 0.7736 & & & 1.0702 \\
\hline Rome and Waterton & Jan-53 & Oct-55 & -0.0137 & 0.9629 & 0.9629 & & & \\
\hline Ohio and Mississippi & Jun-63 & & -0.0179 & 0.8731 & & & 0.8808 & 0.9913 \\
\hline Central Railroad of New Jersey & Jan-66 & & -0.0225 & 0.8941 & & & & 0.8941 \\
\hline Cleveland, Columbus, Cincinnati and Indianapolis & Jul-68 & & -0.0465 & 0.8913 & & & & 0.8913 \\
\hline Chicago, Rock Island and Pacific & Jul-69 & & -0.0484 & 0.9322 & & & & 0.9322 \\
\hline Little Miami & Jan-53 & Nov-55 & -0.0497 & 0.8656 & 0.8656 & & & \\
\hline Norwich and Wor & & Aug-55 & -0.0534 & 0.8066 & 0.8066 & & & \\
\hline
\end{tabular}


Table 4.

Railroads Traded on the New York Stock Exchange and Stock Cumulative Values

Sept 1851-Dec 1870

Individual Companies

\begin{tabular}{|c|c|c|c|c|c|c|c|c|}
\hline \multirow[t]{2}{*}{ Company } & \multicolumn{2}{|c|}{ Date } & \multirow[b]{2}{*}{ Annual Return } & \multicolumn{5}{|c|}{ Cumulative Value (\$) } \\
\hline & First & Last & & Entire Period & 1851-1855 & $1855-1860$ & 1860-1865 & $1865-1870$ \\
\hline Dubuque and Sioux City & Jul-69 & & -0.0720 & 0.8995 & & & & 0.8995 \\
\hline Erie Railroad & & Dec-55 & -0.0825 & 0.6935 & 0.6935 & & & \\
\hline Lake Shore and Michigan Southern & Jun-69 & & -0.1023 & 0.8506 & & & & 0.8506 \\
\hline Madison and Ind & Oct-51 & Sept-54 & -0.1066 & 0.7198 & 0.7198 & & & \\
\hline New York and Erie & Jan-56 & Jul-61 & -0.1317 & 0.4601 & & 0.7555 & 0.6090 & \\
\hline Harlem & & Dec-55 & -0.2014 & 0.3846 & 0.3846 & & & \\
\hline Boston, Hartford and Erie & Jul-68 & & -0.3273 & 0.3836 & & & & 0.3836 \\
\hline Columbus, Chicago and Indiana Central & Jan-69 & & -0.4580 & 0.3092 & & & & 0.3092 \\
\hline Milwaukee and Mississippi & Nov-55 & Jun-59 & -0.6028 & 0.0366 & 1.2195 & 0.0300 & & \\
\hline Lacrosse and Milwaukee & Jul-56 & Dec-58 & -0.7388 & 0.0390 & & 0.0390 & & \\
\hline
\end{tabular}


Table 5

Sharpe Ratios for Industry Portfolios

\begin{tabular}{|c|c|c|c|c|}
\hline$\overline{\text { Industry }}$ & Dates & $\begin{array}{c}\text { Industry } \\
\text { Sharpe Ratio }\end{array}$ & $\begin{array}{c}\text { Market Equally } \\
\text { Weighted Sharpe Ratio }\end{array}$ & $\begin{array}{c}\text { Market Value } \\
\text { Weighted Sharpe Ratio }\end{array}$ \\
\hline$\overline{\mathrm{PCs}}$ & $\begin{array}{l}\text { December } 1983 \text { to } \\
\text { December } 2006\end{array}$ & 0.4516 & 0.4780 & 0.5014 \\
\hline Airlines & $\begin{array}{l}\text { December } 1925 \text { to } \\
\text { December } 1940\end{array}$ & 0.1949 & 0.3627 & 0.2083 \\
\hline $\begin{array}{l}\text { Airplane } \\
\text { Manufacturers }\end{array}$ & $\begin{array}{l}\text { December } 1925 \text { to } \\
\text { December } 1940\end{array}$ & 0.5443 & 0.3627 & 0.2083 \\
\hline Autos & $\begin{array}{l}\text { December } 1912 \text { to } \\
\text { December } 1928\end{array}$ & 0.4821 & - & 0.6392 \\
\hline NYSE Railroads & $\begin{array}{l}\text { September } 1851 \text { to } \\
\text { December } 1870\end{array}$ & 0.0084 & 1.1256 & - \\
\hline
\end{tabular}

Notes: The market indexes are the CRSP market indexes for PCs, airlines and airplane manufacturers. The market index for autos is the Cowles index, which is not available equally weighted. The market index for the railroads traded on the NYSE is the Goetzmann, Ibbotson and Peng index, which is not available market weighted. 